\title{
ASSESSMENT OF WASTE TO ENERGY TECHNOLOGY IN INDONESIA: A TECHNO-ECONOMICAL PERSPECTIVE ON A 1000 TON/DAY SCENARIO
}

\author{
Bayu Prabowo $^{1}$, Fidelis Stefanus Hubertson Simanjuntak ${ }^{2 *}$, Zaki S. Saldi $^{2}$, Yudi Samyudia ${ }^{2}$ \\ Ida Juda Widjojo ${ }^{3}$ \\ ${ }^{1}$ Research and Technology Center, PT. Pertamina (Persero), Jakarta 12950, Indonesia \\ ${ }^{2}$ School of Applied Science, Technology, Engineering, and Mathematics, Universitas Prasetiya \\ Mulya, Tangerang, Banten 15339, Indonesia \\ ${ }^{3}$ School of Business and Economics, Universitas Prasetiya Mulya, Tangerang, Banten 15339, \\ Indonesia
}

(Received: August 2019 / Revised: October 2019 / Accepted: October 2019)

\begin{abstract}
A techno-economic assessment of the implementation of waste to energy (WTE) technology in Indonesia was performed by simulating the business model of a 1000 ton-per-day WTE facility that satisfied a set of economic parameters. Two types of municipal solid waste (MSW) quality were selected for the case study: (1) Low calorific value MSW, $6860 \mathrm{KJ} / \mathrm{Kg}$-as received, taken from the municipal temporary waste collection station in South Tangerang city; and (2) High calorific value MSW, $8970 \mathrm{MJ} / \mathrm{kg}$-as received, taken from a temporary waste collection point in a residential apartment in Jakarta city. For the low calorific value MSW, the base pricing set of IDR 500,000/tons for the tipping fee and IDR 1500/kwh as the electricity selling price was not economically feasible as it resulted in a negative Net Present Value (NPV), a lower Internal Rate of Return (IRR) than the applied Discount Rate (13\%), and a Payback Period (PP) of over five years. It is compulsory to set pricing of either IDR 600,000/tons for the tipping fee or IDR 1750 as the electricity price. In the case of the high calorific value MSW, the base pricing set could be economically feasible as it resulted in an NPV, IRR, and PP of IDR 209.7 billion, $16.38 \%$, and 4.8 years, respectively. Moreover, a reduction in the pricing to either IDR 400,000/tons for the tipping fee or IDR 1350 for electricity may still satisfy the minimum limits of the parameters sets. The results of this study are expected to provide a clearer picture of both the potential and challenges of bringing WTE technology to commercial application, especially in Indonesia.
\end{abstract}

Keywords: Assessment; Economic; Incinerator; Municipal solid waste; Waste to energy

\section{INTRODUCTION}

An increase in human living standards leads not only to greater municipal solid waste (MSW) generated, but also to a shift in its composition toward complex and non-naturally degrading materials such as plastic, glass, metal, and chemical waste. A waste management system capable of handling such large amounts and complex types of waste is therefore important to support the progression of a society. Meanwhile, traditional waste management systems that rely on natural decomposition, e.g., landfill, should eventually be replaced. Inappropriate handling of MSW will lead to health problems and a deterioration of the environment quality. Conversely, a better MSW management system will not only help in solving health and environmental problems but will also generate economic benefits

\footnotetext{
*Corresponding author's email: fidelis.simanjuntak@prasetiyamulya.ac.id, Tel. +62-21-30450500 Permalink/DOI: https://doi.org/10.14716/ijtech.v10i6.3607
} 
Indonesia, with the world's fourth-largest population (260 million people in 2017) faces a state of emergency with regard to its municipal waste problem. About 64 million tons of MSW are produced annually in Indonesia, more than two-thirds of which is disposed of in landfill sites (Rawlins et al., 2014). The remainder is either composted, open-burned, or left completely unmanaged. Bantargebang, as the main disposal site for MSW from the capital city of Jakarta, accepts 6,561.99 tons/day and is predicted to be overcapacity in 2021 (Dinas Lingkungan Hidup DKI Jakarta, 2019). Various methods can be used to convert waste into energy, such as anaerobic digestion for biogas production (Ariyanto et al., 2017) and pyrolysis of waste rubber tires for fuel oil production (Yang, 2016). Waste can also be converted into valuable products, such as compost materials (Hartono et al., 2015).

To accelerate the application of more sustainable waste management, Presidential Decree no.35 regarding the development of waste to energy (WTE) facilities was announced in 2018 (Presidential Decree of the Republic of Indonesia, 2018). In this regulation, 12 big cities, including Jakarta, Bandung, Surabaya, Makassar, and Bali, are expected to immediately establish environmentally friendly WTE facilities. The regulation also established the cost of a feed-in tariff at USD 13.35 cents and a subsidy from the state budget (APBN) of IDR 500,000 per ton of waste toward the waste management fee (tipping fee).

Currently, there are no commercial WTE facilities in operation in Indonesia, with the exception of a 100 ton/day pilot project WTE facility in Bantargebang (Pebrianto, 2019) and the development of a 2,200 ton/day incinerator in Sunter as the country's first commercial WTE plant (Dinas Lingkungan Hidup DKI Jakarta, 2018). The establishment of a WTE facility in Indonesia has been held back by various challenges. Of these, economic challenges usually relate to an inadequate electricity feed-in tariff and the tipping fee. Moreover, the characteristics of Indonesia's waste, which has a high moisture content of up to $60 \%$, may lead to the requirement for an additional pre-treatment facility, thus further raising the costs. The existence of illegal dumpsites as a cheap option for waste disposal (Wisnubro, 2019) serves to make WTE technologies unattractive by comparison. There are also social challenges in the form of opposition from a public concerned about the potential negative impacts of polluting emissions on their health and environment. Such opposition can result in uncertainty around the construction approval process.

In this study, a techno-economic assessment of the implementation of WTE technology in Indonesia was performed by simulating the business model of a 1000 ton-per-day WTE facility. The economic performance of the WTE plant with feeds of low calorific value MSW and high calorific value MSW was analyzed. Moreover, the need to adjust the variables in order to make the technology economically feasible was investigated. The results of this study are expected to provide a clearer picture of both the potential and challenges of bringing WTE technologies to commercial application, especially in Indonesia.

\section{METHODS}

\subsection{Municipal Solid Waste Collection and Characterization}

MSW samples were collected from two different sites: (1) a municipal temporary waste collection station in South Tangerang city; and (2) a temporary waste collection point in a residential apartment in Jakarta city, with the condition of waste that was freshly unloaded from the waste-transporting vehicle. The sample collection was performed at the end of December 2017 between 10.00 and 12.00 a.m. on non-rainy days. Initially, $200 \mathrm{~kg}$ of MSW sample was taken from the waste pile. This was continuously mixed and reduced by half until it reached a mass of $50 \mathrm{~kg}$. This final $50 \mathrm{~kg}$ sample was then segregated based on its type, namely food waste, plastic, inert (glass, metal, sand, etc.), paper, wood, cloth, and other. The heating value and 
moisture content of each type of waste were then measured. The results were multiplied by the fraction of each mass in the MSW sample to obtain the general characteristics of the respective MSW.

The first sample was found to have a moisture content of $56.1 \%$ and a higher heating value of $6879 \mathrm{KJ} / \mathrm{kg}$-as received; thus, it was classified as Low Calorific Value MSW in this study. The second sample had a moisture content of $53.3 \%$ and a higher heating value of $8970 \mathrm{KJ} / \mathrm{kg}$-as received; thus, it was classified as High Calorific Value MSW in this study.

\subsection{Waste to Energy Plant Simulation Model}

The techno-economic performance of WTE technology was analyzed based on the simulation model of a 1000 ton-per-day WTE plant. The working principle of the plant was that it incinerates MSW feed to generate heat energy, which is then further converted to power. The plant's revenue stream is derived from the waste tipping fee and the sale of power, while its costs mainly comprise the energy required for the process, residue dumping, and labor.

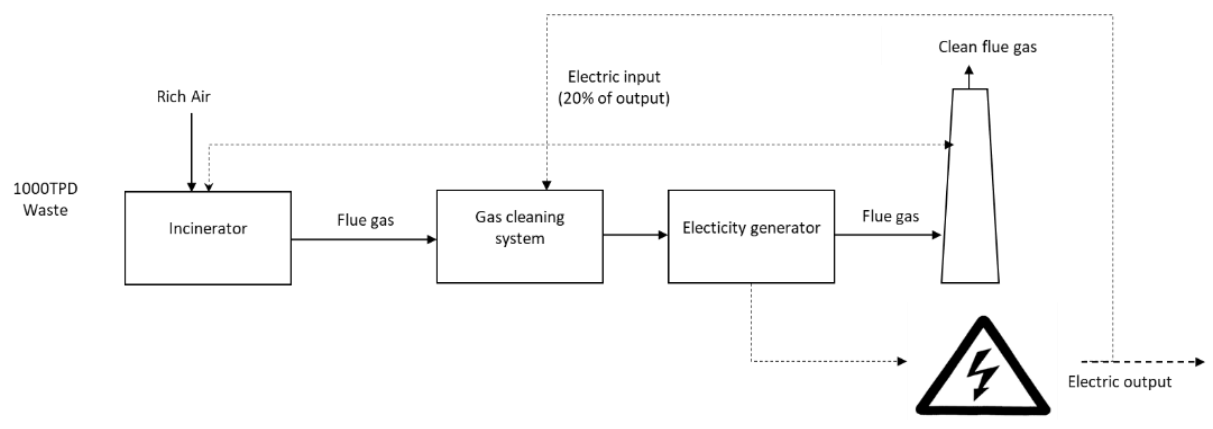

Figure 1 Schematic of waste to energy plant

As shown in Figure 1, the plant process mainly comprises the incinerator unit, gas cleaning system, steam turbine power generator, and flue gas stack. The boundary of this study is limited to the process outlined in Figure 1, while the assumptions applied for the plant's working parameters are given in Table 1.

Table 1 Working parameters of waste to energy plant

\begin{tabular}{lcc}
\hline \multicolumn{1}{c}{ Parameter } & Unit & Amount \\
\hline MSW Input & Tons/day & 1000 \\
Power Generation Efficiency & $\%$ & 25 \\
Parasitic load & $\%$ from power & 20 \\
Plant working days & Days & 324 \\
Number of Plant Operators/Work-shift & Men & 10 \\
Number of Work-shifts/day & Shifts/day & 3 \\
\hline
\end{tabular}

\subsection{Techno-economic Analysis}

The techno-economic assessment was conducted by observing the performance of the WTE plant in generating revenue from the described business process. Net Present Value (NPV), Internal Rate of Return (IRR), and Payback Period (PP) were employed as the performance indicators. The plant was expected to have a service life of more than 10 years; thus, the economic performance was reviewed at the $10^{\text {th }}$ year. The discount rate was conservatively assumed to be $13 \%$. The total plant investment was assumed to be IDR 1,512,000,000,000, funded wholly through equity. Details pertaining to the items of investment are shown in Table 2 , while the detailed operational expenses are given in Table 3 . The basic pricing of the revenue 
streams, namely the waste tipping fee and electricity price, were set at IDR 500,000/ton and IDR $1500 / \mathrm{kwh}$, respectively.

Table 2 Investment items of waste to energy plant

\begin{tabular}{|c|c|c|c|}
\hline \multicolumn{3}{|c|}{ Total Investment (IDR) } & \multirow[t]{2}{*}{$1,512,000,000,000$} \\
\hline & Item & $\begin{array}{c}\text { Specification and calculation } \\
\text { base }\end{array}$ & \\
\hline 1 & Main incinerator facility & 1000 tons per day & $800,000,000,000$ \\
\hline 2 & Main power generator & $25 \mathrm{MW}$ steam turbine & $400,000,000,000$ \\
\hline 3 & Civil construction and licenses & & $300,000,000,000$ \\
\hline 4 & $\begin{array}{l}\text { Training, modification, and auxiliary } \\
\text { adjustments }\end{array}$ & $\begin{array}{c}\text { Waste water treatment, } \\
\text { Mechanical, and electrical } \\
\text { installation }\end{array}$ & $12,000,000,000$ \\
\hline
\end{tabular}

Table 3 Operational expenses of waste to energy plant

\begin{tabular}{|c|c|c|c|c|}
\hline & Expense & IDR/unit & Unit/year & Remarks \\
\hline 1 & Electricity usage & $1,500 / \mathrm{kwh}$ & $30.8-40.4$ mill. & $20 \%$ of power output \\
\hline 2 & Residue disposal & $70,000 /$ ton & 38,880 & $12 \%$ of MSW \\
\hline 3 & $\begin{array}{l}\text { Maintenance and } \\
\text { consumable cost }\end{array}$ & $75,600,000,000 /$ lot & 1 & $5 \%$ of capital cost \\
\hline 4 & Operator & $4,500,000 /$ man-month & 390 & $\begin{array}{c}30 \text { persons for } 3 \text { work- } \\
\text { shifts }\end{array}$ \\
\hline 5 & Administration staff & $4,500,000 /$ man-month & 65 & 5 persons \\
\hline 6 & Security & $4,500,000 /$ man-month & 195 & $\begin{array}{c}15 \text { persons for } 3 \text { work- } \\
\text { shifts }\end{array}$ \\
\hline 7 & Management staff & $15,000,000 /$ man-month & 65 & 5 persons \\
\hline 8 & $\begin{array}{l}\text { Overheads } \\
\text { (communication, } \\
\text { utilities, tax) }\end{array}$ & $390,000,000 /$ month & 12 & $10 \%$ of personnel cost \\
\hline
\end{tabular}

\section{RESULTS AND DISCUSSION}

\subsection{Synt Techno-economic Performance of Waste to Energy Plant with Low Calorific Value Municipal Solid Waste Feed}

As shown in Figure 2, the setting of the tipping fee and electricity tariff at the rates of IDR $500,000 /$ ton and IDR $1500 / \mathrm{kwh}$ resulted in an economically unfeasible WTE plant. This is indicated by the NPV of IDR - 353.03 billion; the low IRR, i.e., $11.3 \%$, compared to the discount rate; and the $\mathrm{PP}$ of 5.81 years.

Sensitivity analysis showed that the minimum satisfying tipping fee is around IDR 600,000/ton. At this rate of IDR 600,000/ton, the plant could be economically feasible with an NPV of IDR 74.9 billion, IRR of $14.2 \%$, and PP of around 5 years. Moreover, the minimum sustaining electricity tariff is around IDR $1650 / \mathrm{kwh}$. At this tariff of IDR $1650 / \mathrm{kwh}$, the plant marginally satisfies the economic parameters with an NPV of IDR 24.53 billion, IRR of 13.4\%, and a PP of around 5.3 years. However, owing to the highly variable nature of MSW and the early stage of maturity of WTE technology, the marginal economic value generated at an electricity tariff of IDR 1650/kwh may prove risky in terms of guaranteeing the economic sustainability of the plant. Therefore, an electricity tariff of IDR 1750/kwh is suggested. 

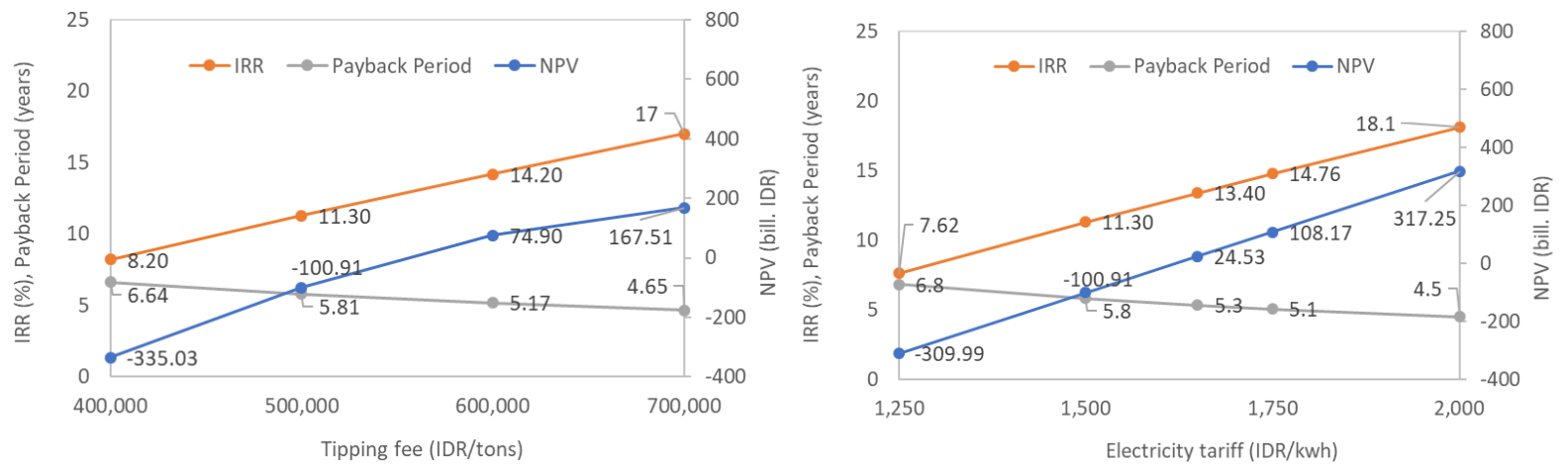

Figure 2 Economic performance of WTE plant with low calorific value MSW

A tipping fee set at IDR 600,000/ton is highly challenging since it is significantly higher than the base price stipulated in the presidential decree (Presidential Decree of the Republic of Indonesia., 2018), i.e., IDR 500,000/ton, and the increment would require a new governing policy. An electricity tariff of IDR $1750 / \mathrm{kwh}$ is just about equal to the price set in the decree. However, the implementation at this tariff might still be challenging since there is a significant disparity with the normal electricity price, i.e., 1467/kwh (Regulation of the Minister of Energy and Mineral Resource of the Republic of Indonesia, 2016). Strong coordination and enforcement from government at all levels are thus essential to ensure that the feed-in-tariff is applicable.

\subsection{Techno-economic Feasibility of Waste to Energy Technology Plant with High Calorific Value Municipal Solid Waste}

As shown in Figure 3, for high calorific value MSW, the tipping fee and electricity tariff base pricing of IDR 500,000/tons and IDR $1500 / \mathrm{kwh}$ respectively could be economically feasible as they result in a WTE plant with an NPV, IRR, and PP of IDR 209.7 billion, 16.38\%, and 4.8 years, respectively. A reduction in the tipping fee to IDR 400,000/tons might still satisfy the minimum limit of the parameter set with an NPV, IRR, and PP of IDR 33.81 billion, $13.56 \%$, and 5.31 years. On the other hand, a reduction in the electricity tariff to IDR 1350/kwh is also likely to satisfy the minimum limit of the parameter set with an NPV, IRR, and PP of IDR 45.41 billion, $13.75 \%$, and 5.27 years.
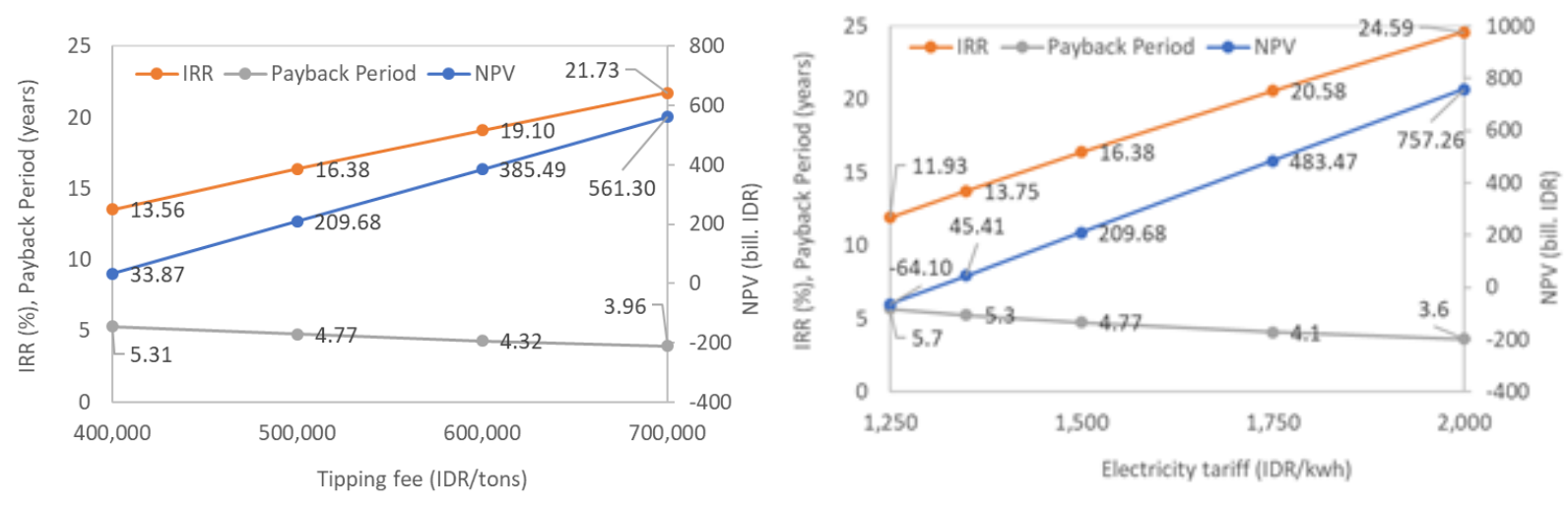

Figure 3 Economic performance of WTE plant with high calorific value MSW

Although the pricing set appears favorable for high calorific value MSW, there is a big challenge in terms of maintaining the calorific value of the MSW by ensuring that the plastic component remains in the waste matrix until it is fed to the WTE plant. Our further technical assessment indicated that the high calorific value of the MSW is highly correlated with the plastic content 
of MSW. On the other hand, waste plastic is a valuable commodity for trade that already has its own market chain (Wirawan, 2018). Therefore, a new regulation should be established governing the working model and involving the waste producer, transporter, and final handler.

\section{CONCLUSION}

A techno-economic assessment of the 1000 ton-per-day WTE facility was conducted with low calorific value MSW, $6860 \mathrm{KJ} / \mathrm{Kg}$-as received, and high calorific value MSW, $8970 \mathrm{MJ} / \mathrm{kg}$-as received. For the low calorific value MSW, the base pricing set of IDR 500,000/tons for the tipping fee and IDR $1500 / \mathrm{kwh}$ for the electricity tariff was not economically feasible as it resulted in a negative NPV, a lower IRR than the applied discount rate (13\%), and a PP of over five years. A pricing adjustment to either a tipping fee of IDR 600,000/tons or an electricity price of IDR 1750 is thus essential. With regard to the high calorific value MSW, the base pricing set could be economically feasible as it produced an NPV, IRR, and PP of IDR 209.7 billion, $16.38 \%$, and 4.8 years, respectively. Moreover, a reduction in the pricing to either IDR 400,000/tons for the tipping fee or IDR 1350 for electricity may still satisfy the minimum limit of the parameter set. However, a big challenge lies in maintaining the calorific value of MSW by ensuring the plastic component remains in the waste matrix until it is fed to the WTE plant. These results provide a clearer picture of both the potential and challenges involved in commercially applying WTE technology, especially in Indonesia.

\section{ACKNOWLEDGEMENT}

The authors gratefully acknowledge the Ministry of Research, Technology and Higher Education of the Republic of Indonesia for its research grant award through PTUPT, Grant No. 493/UN2.R3.1/HKP05.00/2018.

\section{REFERENCES}

Ariyanto, T., Cahyono, R.B., Vente, A., Mattheij, S., Millati, R., Taherzadeh, M.J., Syamsiah, S., 2017. Utilization of Fruit Waste as Biogas Plant Feed and its Superiority Compared to Landfill. International Journal of Technology, Volume 8(8), pp. 1385-1392

Dinas Lingkungan Hidup DKI Jakarta., 2018. Groundbreaking ITF Sunter, Jakarta akan Punya TPA (Groundbreaking of Intermediate Treatment Facility of Sunter, Jakarta will have Intermediate Treatment Facility). Available Online at https://lingkunganhidup.jakarta.go.id/grounbreaking-itf-sunter-jakarta-akan-punya-tpa, Accessed on June 6, 2019

Dinas Lingkungan Hidup DKI Jakarta., 2019. Data-Data TPST Bantargebang (Data at Integrated Waste Management Facility, Bantargebang). Available Online at https://upst.dlh.jakarta.go.id/tpst/data, Accessed on June 6, 2019

Hartono, D.M., Kristanto, G.A., Amin, S., 2015. Potential Reduction of Solid Waste Generated from Traditional and Modern Markets. International Journal of Technology, Volume 6(5), pp. $838-846$

Pebrianto, F., 2019. Gov't Officially Launches Bantargebang Waste-to-Energy Plants. Available Online at https://en.tempo.co/read/1188920/govt-officially-launches-bantargebang-wasteto-energy-plants, Accessed on June 6, 2019

Presidential Decree of the Republic of Indonesia No.35/2018., 2018. Available Online at https://setkab.go.id/wp-content/uploads/2018/04/Perpres-No.-35-Tahun-2018.pdf, Accessed on June 6, 2019

Rawlins, J., Beyer, J., Lampreia, J., Tumiwa, F., 2014. Waste to Energy in Indonesia. Carbon Trust - CTC831. Available Online at https://www.carbontrust.com/media/512147/ctc831waste-to-energy-in-indonesia.pdf, Accessed on June 6, 2019 
Regulation of the Minister of Energy and Mineral Resource of the Republic of Indonesia 2016.

Available

Online at https://www.pln.co.id/statics/uploads/2017/06/Permen-ESDM-No.-28-Tahun-2016.pdf, Accessed on June 6, 2019

Wirawan, J., 2018. Ke mana perginya botol, gelas dan sedotan plastik yang Anda buang? (Where are the plastic bottles, cups and straws gone?). Available Online at https://www.bbc.com/indonesia/majalah-44220235, Accessed on June 6, 2019

Wisnubro, A., 2019. KLHK Segel Tempat Pembuangan Sampah Ilegal di Kota Tangerang (Ministry of Environment and Forestry Banned Illegal Municipal Waste Dumping Site in Tangerang City). Available Online at https://jpp.go.id/humaniora/lingkunganhidup/333093-klhk-segel-tempat-pembuangan-sampah-ilegal-di-kota-tangerang, Accessed on June 6, 2019

Yang, A.L.C., Ani, F.N., 2016. Controlled Microwave-induced Pyrolysis of Waste Rubber Tires. International Journal of Technology, Volume 7(2), pp. 314-322 